\title{
Classifications and \\ moral values in student evaluation boards
}

\author{
Maíra Mascarenhas \\ Fundação Roberto Marinho
}

\begin{abstract}
This article is an analysis of student evaluation board meetings as a space that reveals the classification systems and mechanisms present in the school and which underpin its moral order. Through field work in a federal school in Rio de Janeiro we aimed to understand how these moral criteria form hierarchies which produce different ways of evaluating students, and as a consequence, inequality.
\end{abstract}

Keywords: Moral, inequality, education, student evaluation board.

\section{Resumo}

Este artigo apresenta uma análise dos conselhos de classe como espaços que revelam os sistemas e mecanismos de classificação presentes na escola e que sustentam sua ordem moral. Por meio do trabalho de campo em uma escola federal do Rio de Janeiro, buscou-se compreender como os critérios morais se hierarquizam produzindo avaliações diferenciadas entre os alunos e, como consequência, desigualdade.

Palavras-chave: Moral, desigualdade, educação, conselho de classe. 


\title{
Classifications and moral values in student evaluation boards
}

\author{
Maíra Mascarenhas
}

\section{Introduction}

Student evaluation board meetings are rituals of great importance for the Brazilian school system. They are meetings that take place at the end of each term of the school year ${ }^{1}$ in which the teaching staff - teachers, directors and counselors - meet to assess students' performance. It is at these meetings that the staff share and disclose evaluations and representations on their students as their future is decided ${ }^{2}$.

These evaluations and representations are expressed by categories that comprise the teachers' classification system. Theses classifications are elements of great importance to understand the school system because they are the means through which the organizing principles of the teaching system are expressed.

In his analysis of teachers' judgments in France, Bourdieu noticed that they had a social origin, but teachers were not aware of it, as they saw them in school terms:

It is also because they believe that they are making a strictly school-oriented judgment that the social judgment disguised under the euphemistic principles of their school (or more specifically philosophical) language can produce their own effect: making those who are the subject of these judgments believe that the judgments are applied to the students or the apprentice philosopher in

1 In Brazil, the school year is divided in terms: four two-month terms or three quarters depending on the school's organization. At the end of each term, students take tests and there is a student evaluation board meeting.

2 In most schools, regulations establish that students' passing is subject to the achievement of a minimum grade, which is comprised by the average of the grades obtained on the exams at the end of each term. However, the student evaluation board has the authority to decide on students' approval even if they did not obtain the minimum grade. 
them, to the person and his "intelligence," and never, by all odds, to his social person. (Bourdieu 1999:198)

Judgment by moral criteria is also addressed in studies on Brazilian schools. A pioneering study was that of Schneider (1981) on "special students" in Brazilian public schools. Recently, the study by Sá Earp (2006) described how moral judgment appears in Rio de Janeiro public schools in student evaluation board meetings as well as in classrooms. In addition to Sá Earp's study, other works describe how evaluations based on non-academic criteria occur in Brazilian schools (Carvalho 2001; Prado, Sá Earp, 2011; Gomes 2012; Mascarenhas 2013).

This article aims to reflect on student evaluation board meetings as places that allow a privileged view of the classification systems and mechanisms in schools, their morality and the inequality produced among students. ${ }^{3}$ The proposition behind this approach, is the investigation of the moral dimension of social life, addressing all elements of morality - values, principles and norms - as elements of social life itself. In this regard, we aim not only to understand the school's morality, but also how this morality constitutes and regulates the agents' actions ${ }^{4}$.

To do the research, I followed the daily activities of those working and studying at Colégio Volta Redonda, a public school in the city of Rio de Janeiro, from March 2010 to March 2013, systematically studying the school's everyday activities in all of its environments: classrooms, teachers' room, recess, grade meetings ${ }^{5}$, PTA meetings ${ }^{6}$ and the student evaluation board meetings.

In 2011, I started to teach at the school, which led to a change in my position in the school, because I coupled my activities as a researcher with those of a teacher. In that way, in addition to going to the school to perform my

\footnotetext{
3 This paper leads on from my Master's dissertation (Mascarenhas 2013), whose goal was to understand how the classification systems of teachers and students worked in a public school aiming to investigate the moral values that underlie those classifications. Our goal was also to understand how these systems were related to the interactions between those involved and the production of inequality among the students.

4 Unfortunately, due to this article's scope, I will not be able to deepen the dialogue with sociology and moral, moral feelings and pragmatism anthropology, but I will certainly do it on another occasion.

5 At the grade meetings teachers and the guidance counselors responsible for each grade meet to plan, share and discuss the progress of the work done by the classes in each grade. They take place at the beginning of each quarter - a total of three meetings a year.

$6 \quad$ PTA meetings take place twice a year at Colégio Volta Redonda. Parents are invited to the school and directors, guidance counselors and teachers disclose information on the school's plan and demands for the term.
} 
teaching activities, I also carried out participant observation in the classroom and during recess, student evaluation board meetings and teachers' meetings.

This double insertion had implications in the research methodology. Due to my proximity to the field, it was necessary to implement the saying of Velho (1978) on distancing oneself from that which is familiar as a constant research motto.

The fact that it was my first experience as a teacher contributed to the distancing process, which demanded learning what it means to be a teacher at that school. In many situations, I benefited from the comments and questions of my colleagues who urged for certain attitudes - for example, becoming stricter when correcting the exams of "undisciplined" students - which revealed their expectations towards a teacher's role.

My position as a researcher and a teacher was also of great importance when following the student evaluation board meetings. These rituals are characterized by secrecy in relation to some of the school staff. Becoming "one of them" was important for me to follow these events and witness situations which would probably be carried out in a different way if an outsider were present.

In addition to participant observation, I held formal interviews with eight teachers at the school on their careers and representations on the school. These were crucial complements to the perceptions obtained during field work.

\section{The school - Colégio Volta Redonda}

The Colégio Volta Redonda (CVR), which was founded in 1948, is located in an upscale neighborhood in the city of Rio de Janeiro, with a high Human Development Index (HDI) and one of the highest per capita incomes. It is part of the federal school system and offers morning and afternoon classes from the first year of elementary school to the last year of high school. There are some 700 students and 168 teachers, as well as the director and other employees.

Traditionally the school has been regarded by the general public and the middle class in particular as a traditional and at the same time avant-garde institution attended by the children of the town's elite. This view is associated with the way students are selected, among other criteria. Until the late 199os, students took an admission exam. After that, the exam was substituted by a random draw of the students from the first to the fifth year of elementary 
school. For the high school an exam was adopted and those who scored above the minimum grade (5.0) were then subject to a random draw.

The new rules altered the profile of the students. The teaching staff says the school began to receive students from different social backgrounds, residents of different regions of the city and from different schools, such as municipal and state public schools.

The random draw system was seen as a strategy to democratize the school. As a school principal said: "CVR was seen as a school only for the rich, but that changed a while ago. You can find people from all walks of life here, anyone can study here."

The change in the students' profile is commemorated as one of the school's assets, because it contributes to its role of a public school "for all." But it is also blamed for the school's fall in external evaluations, such as the Development Index of Basic Education (Ideb) that is an indicator of proficiency and school flow, and the National High School Exam (Enem) that tests students' performance at the end of high school, while also serving as an entrance exam for the country's top universities.

A particular feature of Colégio Volta Redonda is the persistence of the rules for expulsion, which forbid the enrolment/continuation of students who fail any grade twice in either elementary school, middle school or high school. The only grade that is not subject to this restriction is the first grade of elementary school.

Although expulsion was often used in Brazilian schools in the past, nowadays it is applied only in a few public schools? ${ }^{7}$. At CVR, however, the persistence of this rule is quite significant, because in the past, being a CVR student was regarded as a sign of distinction. Those who studied there in its first decades stress the strong feeling of belonging and distinction. ${ }^{8}$

Today, the fear of being expelled still exists among students, but due to the changes in the institutional system and the way staff define the school, being expelled has expulsion is no longer as acceptable. Teachers maneuver to avoid expulsion', which is seen as an obstacle in the school's path to democratization:

\footnotetext{
7 In Rio de Janeiro, expulsions endures at Colégios de Aplicação da UERJ and UFRJ and at Colégio Pedro II. More on expulsions at Colégios de Aplicação see Kaiuca (2004) and at Colégio Pedro II see Galvão (2007).

8 There is a relation between school and students similar to that at CVR in Colégio de Aplicação da UFRJ, addressed in the book by Abreu (1992).

9 These strategies consist basically of making the possibility of expulsion a moral criterion of evaluation, as we will see later in this article
} 
We opened the school with the draw and we now have all types of students.

There are those who come from worse public schools - and what should we do?

Lower the standards? Let them be expelled? (Geography teacher)

The staff at CVR believes the school must be democratic, opening opportunities for any student. On the other hand, the expulsion rule is seen as a form of internal selection, which prevents the permanence of students who enter via the random selection system. Thus, the school lets new students in, but cannot make them stay, thus putting its capacity to teach them in doubt.

This produces a permanent conflict in the teaching staff, which is divided between the tendency to expand access and guarantee the permanence of all students - threatening the school's "quality" - and the safeguard of its status by maintaining selection via expulsion. In this way, the school develops its own conceptions of merit and justice which determine the approval or expulsion of students.

\section{The student evaluation board meetings at Colégio Volta Redonda}

As rituals, the student evaluation board meetings take place according to a repetitive structure. At CVR, each of the quarterly meetings is different in terms of content, but not structure ${ }^{10}$.

They take place during the second shift, that is, during the opposite shift of the classes to be addressed. Thus, if classes take place in the morning, the student evaluation board meeting occurs in the afternoon. The participants are the teachers of the classes under discussion, the director of teaching responsible for the grade, and the $\mathrm{SOE}^{11}$ guidance counselor responsible for the pupils ${ }^{12}$. During the student evaluation board meetings, the director, or the guidance counselor addresses each student by his or her name and those participating in the board discuss each student's academic situation and, in many cases, personal aspects, as we will demonstrate later in this paper.

\footnotetext{
10 The student evaluation boards in which I took part were those of the gth year of middle school and the first year of high school. As a researcher, I also was present in the meetings of these grades and also those of the 8th grade of elementary school.

11 Guidance Counselor Sector, responsible for pedagogic following of classes and students.

12 With the exception of the last meeting of the year, in the first part of the meetings, the class presidents are invited to hear and evaluate the teachers and leave after that.
} 
At the first quarterly student evaluation board meeting discussions begin with initial information on the students, because that is when teachers obtain the students' academic and personal information. The second round focuses on discussions on each student's situation highlighting those who are facing difficulties or could fail at the end of the year. During the third round, teachers discuss the students who did not obtain the minimum grade to be approved. Decisions are taken on which students will take remedial classes ${ }^{13}$ and those who will not, even if they did not achieve the minimum grade.

At the final student evaluation board meeting the staff discusses the students who took the remedial classes and were approved or not. It is during this last meeting that decisions are taken about the passing or failing of students who did not reach the minimum grade in the remedial classes. That is, students who did not obtain the minimum grade are not necessarily failed.

The four student evaluation board meetings form a process-they are a sequence of actions as in a drama, whose end is revealed at the final meeting, although, in many cases, final decisions are announced at the very first meeting of the year, as we will demonstrate below.

The observations made during the student evaluation board meetings showed that CVR has characteristics that are very similar to those described in the literature on other schools. The "objective" grade (obtained in exams and projects) is not always the only criterion that determines a student's evaluation, because of the presence of "subjective" factors related to the students' school and extracurricular life.

I believe the "objective/subjective" dichotomy is not enough to apprehend the evaluation process. By observing the student evaluation board meetings and the teaching activities, as well as through my own experience as a teacher, I noticed that the grade is not a result of an "objective" evaluation - it is not free from the teachers' subjective appraisal. From the moment a teacher draws up an exam -choosing its content and the way to test it - to the moment he/she corrects the exams

13 Remedial class period is when extra classes are provided to students who did not obtain the minimum grade to pass. After these classes, students take a new exam and, if they obtain the required grade, they are approved. If not, they are assessed at the final student evaluation board meeting, which can decide to fail them or not. 
and projects ${ }^{14}$, as well as the events of the student evaluation board meetings, teachers' subjectivity interferes in the process that determines each student's grade.

I propose, then, that the students' evaluations are comprised of two values: the "cognitive value" and the "moral value." The cognitive value is expressed by the grades obtained in the exams and projects and aims to measure the level of knowledge apprehended by students. But the "moral value" is comprised of a set of factors such as the students' behavior, appearance, family situation and even health.

The cognitive and moral values are not necessarily similar. A positive value in one of them does not necessarily mean a similar value in the other. An important aspect of the moral value is that it is the result of a set of criteria and it is contextual, varying over time, the individual student concerned and the teacher who is assessing him or her. Thus, different moral criteria can coexist in the evaluation of a single student.

While the cognitive value is expressed by grades and is relatively objective, the moral values can only be understood after an analysis of the student evaluation board meetings.

\section{The categories of the student evaluation board}

An important aspect of the student evaluation board meetings and which determines students' assessment is the level of recognition that each teacher has regarding his/her students. At the meetings I attended, when a teacher did not identify a student by his or her name, he would often ask for the student's physical characteristics, where he or she sat in the classroom or resort to "the little faces" - a list with the names and pictures of the students.

The need to know who each student is suggests that the grade itself (the cognitive value) is not enough for a complete assessment - it is necessary to know about that person, his or her individual characteristics, personality, appearance, background and history.

14 This situation was clear when I followed a teacher correcting the exams of gth grade students. While she corrected a particular student's exam, the teacher drew my attention to some of his answer which did not match the question. She said: "I know he is a good student and knows the content, but look at his answers! He got a 4.o but I know he learned. I'm going to give him an extra half point in these two questions so that his grade will be at least above the average." 
When I was systematizing the emerging categories in the 22 student evaluation board meetings I attended, I noticed some recurrences which showed patterns and conceptions whose meanings were never brought into question.

The students' appearance and personality are often mentioned by the teachers who might classify them as "cute," "annoying," "pretty," "arrogant," "a darling," "sweet," "beautiful". In an extreme case, a biology teacher had this to say about a student of the first year of high school: "My goodness, she is really ugly. Do you know who she reminds me of? Tim Burton's Corpse Bride! I pity, her, I even correct what she writes more kindly, because... poor her!"

A set of recurrent criteria are those regarding school behavior, or, as teachers call it, the student's "attitude." In this set, the main categories are "dedicated," "go-getter," "interested," "engaged". These categories are related to aspects teachers give good evaluations (henceforth called positive categories ${ }^{15}$ ) and are associated with factors such as frequent attendance, participation in class by asking and answering questions, doing school work and observing the rules, as indicated in the statement on a high school first year student:

$\mathrm{P}^{16}$ : She is dedicated.

E: Wow, very! She always asks me questions.

B: She never misses the extra classes.

Pr: That is the kind of student who no one fails.

The criteria mentioned above are related to students' behavior in the face of the school's demands and institutional standards, i.e., the rules and norms that regulate students' social role. These criteria were very important in the teachers' statements when they defended or criticized students at the final student evaluation board meeting, such as in the comment made by a Mathematics teacher on one of his students: “He's 0.2

15 Positive and negative are categories I used not only to describe the value teachers attribute to the students in the context at stake, but these categories also contribute to a student's good or bad assessment. The value is not absolute, it's contextual.

16 In this article teachers are identified by the first letter of the subject they teach. 
short, but I decided to give it to him. He is very dedicated he's asked me for help, attended the extra classes in the afternoon and sought the interns to clarify doubts."

As opposed to the positive categories, the negative categories are those which produce lower evaluations and represent challenging behavior regarding school demands:

1-B: People, he is that case, his effort this year was nonexistent -- he's never been so uninterested.

P: Yes. The fact is that he really doesn't want to do anything.

F: But the boy is throwing an opportunity out of the window, isn't he? [In a harsh voice]

B: He doesn't attend remedial classes either.

B: He doesn't care, he just doesn't want to. He is very apathetic.

2- G: His problem is that he is totally disrespectful. He is not committed; he thinks he can do whatever he wants, that his father is going to buy him the world.

P: He doesn't want anything. He doesn't have the right attitude. He is completely uninterested.

H: He will get nothing from me, if he needs one point at the end of the year, I won't give it.

$G \mathrm{D}: \mathrm{He}$ is a problem.

3- GD: Ok, then. Rafael will attend Geography remedial classes, and that's all.

G: He is going to because he didn't hand in his projects. He is very irresponsible and lacks commitment.

H: Look, this boy is intelligent, but has a bad character. To be honest, I can't stand him. (Raising his voice) 
B: Me neither, I have to stand him. He is very rude and has no limits. He just wants to do absolutely nothing.

G: We have to give him limits.

B: In his case, nothing is negotiable. I'll give him nothing if he needs help. He doesn't deserve it!

As the dialogues above show, in this set there are expressions such as the student "wants to do nothing", "sleeps in class," "lacks commitment," "is negligent", "apathetic," or "uninterested". In the cases of the students who received such evaluations, the teachers seldom interfered or took positions to favor the evaluation, because the moral values were very low. As the biology teacher said: "he doesn't deserve it."

Along with behavior aspects, we also find criteria connected with cognitive difficulties, present in oft repeated sentences like: "he is limited," "it doesn't run smoothly," "he lacks a basis," "he is immature/lacks maturity," "a typical municipal school student," is having much trouble." The cognitive difficulty appears as a positive category when associated with the idea of effort, as in the conversation below:

GD: Cícero.

B: Guys, he is very dedicated. Poor guy, he comes to me with his notebook after the class, but ruins my coffee break.

(The other teachers laugh)

M: He is limited, and that's that. But he is a go-getter.

$\mathrm{P}$ : He is a more difficult case, making him get grades above the average is expecting too much.

GC: He has trouble, his highest grades are the minimum to pass. He failed $8^{\text {th }}$ grade and was approved by the student evaluation board last year. We must give him a chance. 
However, cognitive difficulties can also worsen a negative situation when they are not coupled with a form of "positive" behavior:

M: When he wants and when he studies, he makes progress. But most of the time he just does nothing, shows no concern.

B: I have a student, for example, who has a lot of trouble learning but he passes without remedial classes. He has trouble, but he is also negligent, he is a feet-dragger. He is very apathetic.

A category of great importance is that of students who are "at risk of being expelled.” At every student evaluation board meeting I attended, attention was paid to students who were facing this risk and, in almost all cases the possibility of being expelled superseded the other evaluation criteria at the moment of deciding whether they should be approved or failed.

It is very important to highlight that the possibility of expelling a student is a moral criterion because the teachers see the possibility of being a CVR student as a privilege, as shown in a teacher's statement on the possible expulsion of student Felipe:

GD: Felipe. He will take remedial classes in Physics, Math, Biology, English and Geometric Drawing. He only passed Geography and History.

P: He’s a very bad student.

GC: I'm a little worried because it is a case of expulsion. His family is poor and his parents don't have a good education. Everything he has achieved has been his own merit as well as ours.

M: His exam wasn't bad. But it is very difficult for him -- he is not a high school student

GC: You do remember that it is a case of expulsion.

M: I know it's bad to expel in a case like this, but we cannot pretend that his grades don't exist. 
$\mathrm{H}$ : If he passes now, we will certainly fail him next year. We would be postponing the problem.

GD: Look. I would like you to deal with this case carefully, because CVR is his only chance of studying at a good school.

C: I can tell you he won't pass Chemistry next year. I think it could be even sadder to see this boy suffer and not end his next year.

P: I can say I have a lump in my throat - it's a hard choice to make.

This was one of the tensions which resulted from the school's change in accepting students. As mentioned above, after the random selection process began, teachers identified that the students' profile became more diverse, and a result, quality in the school declined. Before that, students were seen as more qualified - either because of their background or their success in the admission exam - and expulsion was seen as a selection mechanism and a way of maintaining the school's level. The change shifted the approach to a personal question, bringing the privation of an opportunity into play.

Beyond the "school" criteria, there is also a series of criteria regarding students' lives out of school. The use of drugs, romantic relationships and attendance at parties out of the school, for example, are subject to the teachers' moral judgment. In these cases, the transformation of the social and moral issues is made clear, even though they have nothing to do with academic demands, or schools issues (Bourdieu 1999).

In the same way, personal and family "dramas" emerge as elements of the composition of moral value. It is interesting that many times such information was disclosed often by the guidance counselors or one of the directors, but also by teachers who asked: "But, does she have a story?" A student's "story" appears as an element to explain the student's academic situation.

The student's family's socioeconomic situation also emerges as important information, because it is seen as a factor that interferes in the students' performance:

GC: Guys, Felipe's family is very poor, his mother is nearly illiterate. So any performance he might have is a lot in comparison with his background. 
$\mathrm{H}$ : He shows quality - when he wants to. But he just has no interest. When he does something, he does it well, but he really is reluctant to get started.

M: It's self boycott. He is on his way to stay back.

C: And he has another serious problem as he is excluded in class. He is ashamed of his father being a janitor and of living in Rocinha slum.

GC: He doesn't believe in himself. He thinks that "if my family is poor, how can I have this potential?" He probably questions himself.

$\mathrm{H}$ : Also his social origins and his race must have an influence.

In these dialogues, we can notice that the student's socioeconomic status emerges when his or her cognitive value is low, which seems to indicate that a low socioeconomic position adds positive value in the assessment of students with low cognitive performance. A poor background is one of the explanations for their poor performance in school, and, since it is considered beyond the student's ability to change, it contributes to the student receiving a good evaluation. I believe this logic is associated with the change in perception of the school's role and the background of the students accepted by the random selection process.

The students' health conditions appear as "attenuating" circumstances when their academic performance is inadequate and also as one of the reasons for their teachers' low expectations, as one of the directors said about a student who had cancer and another who was hearing-impaired: "I think that in the cases of the students like Luisa and Cícero, we have to think about what they can give and not on what we can ask from them (...). We have to try and make them give the best they can."

Often teachers referred to students suffering from psychiatric disorders, especially Attention Deficit Disorder (ADD), or those who use medication such as Ritalin ${ }^{17}$.

GC: He has ADD. But there is another problem: his mother doesn't take him to the doctor and she medicates the boy herself (...) Also she gives him Frontal ${ }^{18}$ every once in a while. So we never know if he's under the effect of

17 Medicine used in ADD treatment.

18 Anxiolytic medicine. 
medication; we have to guess by his behavior. When he is more agitated and his grades are low we know that he's not been medicated. And she came to school to talk and said that he is now developing OCD ${ }^{19}$.

This case demonstrates that the family is another extracurricular criterion used to evaluate students, as indicated by these comments made during student evaluation board meetings: "God, I want to hit her father!"; "That father is a unbelievable!;" "The boy is the same as his father;" "I defend him a lot, because with a mother like that, he is working miracles!"

The intra-school and extracurricular criteria are structural. However, they are invoked in specific situations and end up influencing the teachers' evaluation and overshadowing negative criteria.

\section{The scale of morality, a classification hierarchy}

As moral value is comprised of a set of moral and contextual criteria, during student evaluation board meetings, the categories that appear are combined and their meaning is forged according to the situation involved. But still, there is regularity in what the teachers say; after all, classificatory systems are collective by definition (Durkheim 2000).

When we look at the set of categories gathered during each meeting, we can identify patters of meaning. Table 1 contains the categories that appeared during the meetings I attended ${ }^{20}$, grouped according to whether they were positive or negative, academic or non-academic.

We deduce that there are more negative categories than positive ones, and the majority of the negative ones apply to academic values.

When we plot all categories applied to each student, as shown in Tables 2, 2.1 and 2.2, we see that some are more "classified" than others, while there are cases in which teachers say very little if anything at all about a particular student. These students are made "invisible" by the teachers and do not draw the attention of the board.

When we turn to the ethnography of the meetings, we tend to see that the "invisibilized" students are those whose grades are above average and who behave according to the standards expected by teachers. They are not

19 Obsessive compulsive disorder.

20 To guarantee anonymity, the categories were removed from the first student evaluation board meeting of three classes in 2012. 
mentioned at the meetings because their grades are good enough and their behavior doesn't justify praise or criticism. Perhaps these are the students for whom the moral value is not a determinant component in their assessment; only their school marks matter.

Table 1

\begin{tabular}{|c|c|c|c|}
\hline \multicolumn{2}{|r|}{ Positive } & \multicolumn{2}{|c|}{ Negative } \\
\hline Academic & Non-academic & Academic & Non-academic \\
\hline $\begin{array}{l}\text { He/she doesn't } \\
\text { cause trouble }\end{array}$ & Mature girl/ Leader & $\mathrm{He} /$ she has given up & Arrogant \\
\hline $\begin{array}{c}\text { He/she never miss- } \\
\text { es a class }\end{array}$ & $\begin{array}{c}\text { Abandoned by his/her } \\
\text { mother }\end{array}$ & $\begin{array}{c}\text { He/she has trouble fol- } \\
\text { lowing classes }\end{array}$ & $\begin{array}{l}\text { He/she has low } \\
\text { self esteem }\end{array}$ \\
\hline Great student & He/she lives far & $\begin{array}{c}\text { He/she doesn't make an } \\
\text { effort }\end{array}$ & A big baby \\
\hline $\begin{array}{c}\text { He/she clarifies his } \\
\text { her doubts }\end{array}$ & $\begin{array}{l}\text { He/she lives in Ro- } \\
\text { cinha slum }\end{array}$ & $\begin{array}{c}\text { He/she has been ap- } \\
\text { proved by the student } \\
\text { evaluation board }\end{array}$ & $\begin{array}{l}\text { A complicated } \\
\text { case }\end{array}$ \\
\hline Good student & $\begin{array}{l}\text { He has a dark com- } \\
\text { plexion }\end{array}$ & $\begin{array}{l}\text { He/she understands } \\
\text { nothing }\end{array}$ & Annoying \\
\hline $\begin{array}{l}\text { He/she goes to } \\
\text { extra classes }\end{array}$ & Nothing special & $\begin{array}{l}\text { He/she doesn't work } \\
\text { hard }\end{array}$ & Disrespectful \\
\hline Good enough & Hearing impaired & He/she doesn't care & $\begin{array}{c}\text { He/she has a bad } \\
\text { attitude }\end{array}$ \\
\hline Dedicated & $\begin{array}{c}\text { He/she has nowhere to } \\
\text { study }\end{array}$ & He/she does nothing & Underhand \\
\hline $\begin{array}{c}\text { He/she studies } \\
\text { hard }\end{array}$ & Financial difficulties & A difficult case & Bad influence \\
\hline Asks questions & Great/ Excellent & Very likely to fail & Weird \\
\hline Genius & Polite & $\begin{array}{l}\text { He/she doesn't do any } \\
\text { work }\end{array}$ & Closed person \\
\hline Intelligent & $\begin{array}{l}\text { His/her father is un- } \\
\text { employed }\end{array}$ & $\begin{array}{l}\text { He/she talks all the } \\
\text { time }\end{array}$ & $\begin{array}{c}\mathrm{He} / \text { she is an only } \\
\text { child }\end{array}$ \\
\hline $\mathrm{He} /$ she has failed & His/her father is dead & $\begin{array}{l}\text { Uncommitted/Unin- } \\
\text { terested }\end{array}$ & Immaturity \\
\hline Expulsion & $\begin{array}{l}\text { He/she lost his/her } \\
\text { father }\end{array}$ & He/she has difficulties & Detestable \\
\hline
\end{tabular}




\begin{tabular}{|c|c|c|}
\hline Poor & A problem/Worrying & Rude \\
\hline English poise & $\begin{array}{c}\text { He/she shows no inter- } \\
\text { est }\end{array}$ & Rascal \\
\hline $\begin{array}{c}\text { He/she has a difficult } \\
\text { family background }\end{array}$ & $\begin{array}{l}\text { He/she has trouble } \\
\text { concentrating }\end{array}$ & $\begin{array}{l}\text { He/she has a bad } \\
\text { character }\end{array}$ \\
\hline $\begin{array}{c}\text { His/her family is edu- } \\
\text { cated }\end{array}$ & $\begin{array}{l}\text { He/she has poor dex- } \\
\text { terity }\end{array}$ & Spoiled \\
\hline He/she has sequels & $\begin{array}{c}\text { He/she doesn't partici- } \\
\text { pate }\end{array}$ & He/she uses drugs \\
\hline He/she has OCD & $\begin{array}{c}\text { He/she wants to do } \\
\text { nothing }\end{array}$ & $\begin{array}{c}\text { He/she came from } \\
\text { a municipal public } \\
\text { school }\end{array}$ \\
\hline The family cannot help & $\begin{array}{c}\text { He/she doesn't help } \\
\text { himself/herself }\end{array}$ & Family problems \\
\hline $\begin{array}{c}\mathrm{He} / \text { she takes medicine } \\
\text { to lose weight }\end{array}$ & $\begin{array}{l}\text { He/she doesn't work } \\
\text { hard }\end{array}$ & $\begin{array}{c}\text { A product of auto- } \\
\text { matic approval }\end{array}$ \\
\hline $\begin{array}{c}\text { He/she takes Ritalin } \\
\text { and Frontal }\end{array}$ & $\begin{array}{l}\text { He/she has much dif- } \\
\text { ficulty }\end{array}$ & Quiet \\
\hline Easy-going & $\mathrm{He} /$ she lacks basis & Solitary \\
\hline $\begin{array}{l}\text { Lovely/ Darling/ } \\
\text { Sweety }\end{array}$ & He/she lacks interest & Reserved \\
\hline Excluded/Weakened & $\begin{array}{c}\text { He/she misses many } \\
\text { classes }\end{array}$ & Reticent \\
\hline $\begin{array}{c}\text { He/she has a compli- } \\
\text { cated background }\end{array}$ & He/she has no capacity & $\begin{array}{l}\text { He/she boycotts } \\
\text { himself/herself }\end{array}$ \\
\hline He/she has a hard life & $\begin{array}{c}\text { He/she is on the phone } \\
\text { all the time }\end{array}$ & Sleepy \\
\hline $\begin{array}{l}\text { He/she is a victim of } \\
\text { his/her father's ab- } \\
\text { sence }\end{array}$ & $\mathrm{He} /$ she has no limits & $\mathrm{ADD}$ \\
\hline Love/ A sweetheart & $\mathrm{He} /$ she is likely to fail & agitated \\
\hline Short & $\begin{array}{l}\text { He/she doesn't go to } \\
\text { extra classes }\end{array}$ & Apathetic \\
\hline Good /Good girl & $\begin{array}{l}\text { He/she doesn't value } \\
\text { school }\end{array}$ & Timid \\
\hline Ugly girl & $\begin{array}{l}\text { Irresponsible/ Suspi- } \\
\text { cious } \\
\end{array}$ & Shy \\
\hline Pretty/Cute & Limited/Weak & $\begin{array}{l}\text { Typical munici- } \\
\text { pal public school } \\
\text { student }\end{array}$ \\
\hline $\begin{array}{c}\text { He/she has a cyst in } \\
\text { his/her head }\end{array}$ & $\begin{array}{c}\text { He/she shows quality } \\
\text { when he/she wants }\end{array}$ & Marijuana gang \\
\hline Poor little girl & $\begin{array}{l}\text { He/she has trouble } \\
\text { reading and writing }\end{array}$ & \\
\hline
\end{tabular}


Table 2

\begin{tabular}{|c|c|c|}
\hline \multirow{2}{*}{ Name } & \multicolumn{2}{|c|}{ Categories from the student evaluation board } \\
\hline & Positive & Negative \\
\hline \multirow{6}{*}{ Adriane } & \multirow{2}{*}{ Easy-going } & Agitated \\
\hline & & She has difficulty \\
\hline & & She doesn't care \\
\hline & & She sleeps in class \\
\hline & & A serious problem \\
\hline & & She talks in class \\
\hline A. Carolina & Nothing special & \\
\hline \multirow{3}{*}{ André } & Cute & He is an only child \\
\hline & Spoiled & Annoying \\
\hline & Good & A big baby \\
\hline Bernardo & $\begin{array}{l}\text { He has a difficult family back- } \\
\text { ground }\end{array}$ & $\begin{array}{c}\text { He has been approved by the stu- } \\
\text { dent evaluation board }\end{array}$ \\
\hline \multirow{4}{*}{ Carolina } & She has financial difficulties & $\begin{array}{l}\text { She has been approved by the } \\
\text { student evaluation board }\end{array}$ \\
\hline & Dedicated & She has trouble \\
\hline & She has low self esteem & \\
\hline & Never misses class & \\
\hline \multirow{3}{*}{ Carina } & Ugly & Quiet \\
\hline & Poor little girl & Sleepy \\
\hline & $\begin{array}{l}\text { She takes medicine to lose } \\
\text { weight }\end{array}$ & \\
\hline \multirow{3}{*}{ C. Eduardo } & English poise & \\
\hline & Arrogant & \\
\hline & His family is educated & \\
\hline \multirow{4}{*}{ Cícero } & Dedicated & A difficult case \\
\hline & He asks questions & $\begin{array}{c}\text { He has been approved by the stu- } \\
\text { dent evaluation board }\end{array}$ \\
\hline & & He has failed a grade \\
\hline & & Limited \\
\hline
\end{tabular}




\begin{tabular}{|c|c|c|}
\hline \multirow{4}{*}{ Daniel } & Great & \\
\hline & Good student & \\
\hline & He has a dark completion & \\
\hline & Short & \\
\hline & Intelligent & \\
\hline & A sweetheart & \\
\hline & Polite & \\
\hline \multirow{4}{*}{ Daniela } & Weak & \\
\hline & Underhand & \\
\hline & Limited & \\
\hline \multirow{4}{*}{ Davi } & He has a cyst in his head & \\
\hline & His father is dead & \\
\hline & He has a complicated background & \\
\hline \multirow{4}{*}{ Elisa } & She doesn't cause trouble & \\
\hline & Good girl & \\
\hline & Genius & \\
\hline & Great & \\
\hline & Lovely & \\
\hline & Darling & \\
\hline & & \\
\hline & & \\
\hline & & \\
\hline
\end{tabular}

Table 2.1

\begin{tabular}{|c|c|c|}
\hline \multirow{4}{*}{ Name } & \multicolumn{2}{|c|}{ Categories from the student evaluation board } \\
\cline { 2 - 3 } & Positive & Negative \\
\hline \multirow{4}{*}{ Felipe } & Worrying & Reserved \\
\cline { 2 - 3 } & Poor & Suspicious \\
\cline { 2 - 3 } & He lives in Rocinha slum & Reticent \\
\cline { 2 - 3 } & Excluded & Self boycott \\
\cline { 2 - 3 } & & Solitary \\
\cline { 2 - 3 } & & Uninterested \\
\hline
\end{tabular}




\begin{tabular}{|c|c|c|}
\hline \multirow{4}{*}{ Gabriel } & Poor little boy & He has lost his father \\
\hline & & Closed \\
\hline & & Weakened \\
\hline & & Weird \\
\hline \multirow{6}{*}{ Gabriela } & Intelligent & She misses many classes \\
\hline & & She uses drugs \\
\hline & & She has family problems \\
\hline & & She sleeps in class \\
\hline & & A problem \\
\hline & & Uninterested \\
\hline \multirow{2}{*}{ Guilherme } & Expulsion & He doesn't make an effort \\
\hline & & He doesn't value school \\
\hline \multirow{5}{*}{ Ingrid } & $\begin{array}{l}\text { She has cognitive dif- } \\
\text { ficulty }\end{array}$ & Typical municipal school student \\
\hline & & She understands nothing \\
\hline & & A product of automatic approval \\
\hline & & She lacks basis \\
\hline & & Immaturity \\
\hline \multirow{5}{*}{ Júlia } & Cute & She talk too much \\
\hline & Great & \\
\hline & Sweety & \\
\hline & Excellent & \\
\hline & Mature & \\
\hline \multirow{7}{*}{ Juliana } & $\begin{array}{l}\text { She has financial dif- } \\
\text { ficulty }\end{array}$ & She has given up \\
\hline & & She does nothing \\
\hline & & She came from a municipal school \\
\hline & & She doesn't help herself \\
\hline & & She doesn't go to extra classes \\
\hline & & She is likely to fail \\
\hline & & She doesn't show interest \\
\hline
\end{tabular}


Table 2.2

\begin{tabular}{|c|c|c|}
\hline \multirow{2}{*}{ Name } & \multicolumn{2}{|c|}{ Categories from the student evaluation board } \\
\hline & Positive & Negative \\
\hline \multirow{7}{*}{ Lucas } & & A problem \\
\hline & & He has a bad attitude \\
\hline & & Disrespectful \\
\hline & & Uncommitted \\
\hline & & He wants nothing \\
\hline & & Uninterested \\
\hline & & Marijuana gang \\
\hline \multirow{2}{*}{ Luisa } & Good enough & \\
\hline & Hearing impaired & \\
\hline \multirow{6}{*}{ Matheus } & Lovely & He has trouble concentrating \\
\hline & ADD & A complicated case \\
\hline & He takes Ritalin and Frontal & He has a lot difficulty \\
\hline & He has OCD & He asks questions \\
\hline & He goes to extra classes & \\
\hline & He studies & \\
\hline \multirow{4}{*}{ Pedro } & & He doesn't have trouble \\
\hline & & Apathetic \\
\hline & & He doesn't participate \\
\hline & & He does nothing \\
\hline \multirow{6}{*}{ Rafael } & Leader & \multirow{2}{*}{$\begin{array}{c}\text { He has a bad character } \\
\text { He has no limits }\end{array}$} \\
\hline & $\begin{array}{l}\text { A victim of his father's ab- } \\
\text { sence }\end{array}$ & \\
\hline & Intelligent & Irresponsible \\
\hline & & Uncommitted \\
\hline & & Irresponsible \\
\hline & & Rude \\
\hline \multirow{7}{*}{ Tatiana } & Expulsion & A bad influence \\
\hline & & She does nothing \\
\hline & & She has a lot of difficulty \\
\hline & & Rascal \\
\hline & & She has no capacity \\
\hline & & She doesn't make an effort \\
\hline & & Likely to fail \\
\hline
\end{tabular}




\begin{tabular}{|c|c|c|}
\hline \multirow{4}{*}{ Tales } & Abandoned by his mother & He has trouble following classes \\
\cline { 2 - 3 } & Hard life & He doesn't make an effort \\
\cline { 2 - 3 } & He has nowhere to study & He has been approved by the board \\
\cline { 2 - 3 } & Financial difficulties & Timid \\
\hline
\end{tabular}

Given the great variety of categories mentioned at student evaluation board meetings and also the contextual aspect of their meanings, it is very difficult to understand the school classificatory system only in terms of macro sociological categories, such as race, gender and class, although these are certainly present in the meetings.

On gender, Tables 2, 2.1, 2.2 show that the negative categories are more recurrent in the male group, which might indicate that they receive bad assessments while girls tend to receive better evaluations. This issue is addressed by the literature of the sociology of education (Barbosa, Randall 2004; Carvalho 2001), but in the case of CVR, it was not possible to identify a clear pattern.

Race was present in some teachers' opinions on the relations established among students, suggesting that discrimination or lack of acceptance worsens their academic situations. At CVR, this category emerged few times during fieldwork, usually spoken very carefully by a teacher or guidance counselor to refer to conflicts between students. The difficulty of acknowledging these conflicts and the significance of race in evaluating pupils doesn't mean they are nonexistent.

As shown before, the issue of social class is present as the teachers make their evaluation at the meetings, because a student's socioeconomic background is often taken into account. However, I do not believe that the moral evaluation that occurs at the school is simply a mechanism that reproduces socioeconomic inequality.

Although the weight of the criteria varies in the evaluation of each student, it is possible to apprehend that bringing these criteria to the meetings is a way to reproduce the inequalities among students, after all, opportunities are given or not to students according to the criteria used to assess them.

In this sense, I believe that it is possible to understand the existence of a scale of morality on which the area of agency and the students' decisions are weighed in the face of the school's demands and institutional standards. It 
is important to note that "the school's demands and institutional standards" do not refer only to the rules and norms in the school's codes, but also to those implicit rules that govern staff behavior and teachers' expectations towards students.

In the scale of morality, the lowest values attributed to the situations in which students go willfully against the school's rules and norms, for instance, as in cases of violent attitudes. In the same area we can find the actions identified as "uninterested," being labeled as a "layabout" or "wants nothing". These are followed by behavior regarded as a consequence of a problematic family background.

Among the most valued qualities and situations, and which produce more "indulgent" evaluations, are the students who, despite their "effort," cannot overcome their intellectual limitations identified by the teachers. Finally, the extreme cases of positive appreciation are those in which there is some tragedy or dramatic situation in a student's life. Here is a graphic representation of the scale:

\section{Scale of morality}

Individual agency $x$ the school's institutional demands

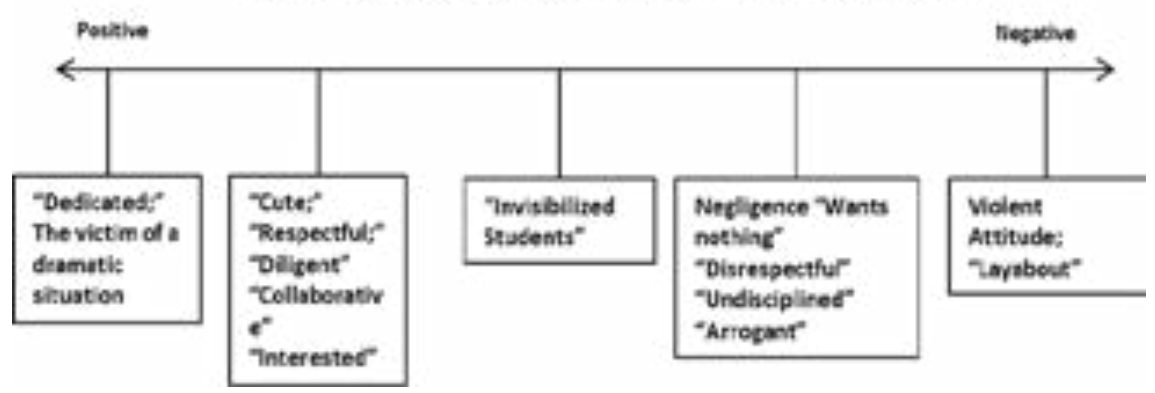

The scale of morality establishes a hierarchy of values and situations that might be brought up during a student evaluation board meeting. Each meeting generates its own hierarchy. However, I believe that there is a general pattern in the principles that comprise the scale of morality forged in the tension between the students' range of action and the school's rules and standards.

The scale of morality helps us understand the relation between moral value and cognitive value. If a student is given low moral value, his or her 
cognitive results will not be altered during evaluation. If, on the other hand, a student is classified with high moral categories, these may have a positive influence on his final evaluation.

\section{Failing as punishment, vengeance and opportunity}

The student evaluation board meetings are directly linked to the fail/ approval logic that underlies Brazil's entire educational system. Ultimately, their existence and occurrence are connected to the final decision to approve a student or not. As already noted, this decision is not limited to the last meeting of the year, but it may be present from the first meeting onwards, with a clear anticipation of failure for a certain number of students- a characteristic of the "pedagogy of failure" proposed by Sergio Costa Ribeiro $(1991)^{21}$. At the first CVR meetings that I followed, only three months after the beginning of the classes, I came across teachers who showed disbelief in some students' capacity to pass, with sentences such as: "he is on his way to staying behind," "he isn't going to pass," "he is likely to fail." The process of failing certain students began during the very first meeting, even if, in most cases, it was announced only at the end of the year.

Failure had different meanings for the teachers in the cases discussed. This multiplicity of meanings can be understood better through an example of a student in the first year of high school: Tales had not obtained sufficient grades to be approved in three classes, and teachers discussed his academic future at the last student evaluation board meeting.

Those in favor of failing him said he had not learned enough in the classes taught that year and was not equipped to move into the next year: "He is a student who has a lot difficulty, I don't see him moving to the next grade;" "I think that he shouldn't pass -- for his own good. If he goes on to the next grade, it will be chaos;" "I wonder if making him stay back with younger students will make him level (...) Perhaps it is best for him to stay back".

The Drama teacher had a different opinion and believed that passing the student would be best, as the following dialogue shows:

21 Available at: www.sergiocostaribeiro.ifcs.ufrj.br 
D: Failing can be good, it's good for some people, but will it be good for him? He already has low self-esteem. We preach that this is a school with such and such characteristics; that it isn't a case for punishment, but I believe he is fragile. I think that we have to put ourselves in his shoes, he has little support.

P: You are speaking of punishment again, and that is not what we are discussing. Failing isn't like punishment, it's a way of developing his capacities.

D: I believe, and I will be repeating myself, that there are different kinds of fail. If everybody tried to help him throughout the year and he did nothing, that means he is a rascal.

P: But in that case, failing is punishment.

D: It's not punishment. It's education, it's different, it's another conception. I think we should think this through.

As shown above, failing can be defined as an opportunity for students to learn what they didn't manage to learn or "grow up"; it can also work as a mechanism of punishment, disapproval of certain behavior, or, ultimately, revenge.

Passing, as a structural equivalent of failing, also has different meanings in different situations. In the case below it appears as an opportunity for a student to continue in the school, as a positive influence on the student's "self-esteem" ${ }_{22}$, or even as a "prize." This meaning can be apprehended by analyzing the case of Gabriela, a student in the first year of high school:

GC: Now, Gabriela. She didn't pass in Mathematics and failed all terms in Physics.

M: Throughout the year, she showed no interest in school. What is most noticeable in her is her total nihilism. She just doesn't care.

22 "Self-esteem" is a native category used by the teachers. 
C: She is very intelligent, she could have done it, but she let things get to this point.

GC: It's hard to mention this, but she has a conflict with her parents. Her mother protects her father - a violent man. So she is stuck between a father who is an animal and a mother who lets her do whatever she wants. Didn't she improve in your classes?

Principal: Her mother said that she was studying hard and not going out at all. But in my opinion, if she can't pass, then that's it. She slept late, she skipped class, she did whatever she wanted and her mother let her.

GC: There is the drug problem, too.

$\mathrm{P}$ : She is quite mature, I just think that I don't feel comfortable in approving her in this meeting. And it's not because of her grades. She is one of those cases: are we sending the right signal here? As far as I'm concerned, I believe it's best to fail her.

M: She slept through the year.

$\mathrm{P}$ : The thing is that her problem with marijuana was crucial, it really brought her down. It's complicated.

M: I agree with you - passing will look like we are giving her the green light.

GD: I think this thing of "she could have passed, but she chose to give up" is quite complicated.

M: She missed all exams. She has trouble with Math and she doesn't deserve a chance. I think failing will do her good, she will wake up.

G: I think that she has very good qualities. She's made mistakes but she has what it takes.

P: I think that it's very bad when we fail a student, but we usually see that he or she can't do it. But in Gabriela's case, we know that she can. There is issue of 
age - what message will we be sending her? What was she doing? She skipped class to smoke marijuana at the entrance with the boys. So I ask myself what kind of message we will be sending her -she can do that and nothing will happen? I don't feel comfortable approving her, either.

B: If we look at her grades, like we did with Tales, we have to approve her, but there are other things at stake.

GD: Guys, don't get me wrong, but a lazy person cannot be awarded anything. She's a smart girl, but she doesn't want anything -- it just can't be. (Raising his voice)

Although some of the teachers highlighted characteristics such as her "intelligence" and "maturity" and guaranteed that she has the "capacity" to move on to the next grade, elements in Gabriela's behavior were crucial to her failing: skipping classes, sleeping during classes, smoking marijuana, "wants nothing", "gave up." The predominance of behaviors evaluated negatively and the punishing aspect of her fail were evident in the director's last comment, which ended the discussion. Teachers voted against her approval.

\section{Final remarks}

Failing is a central element in the logic of the Brazilian school system. Its function is not only practical - preventing students who "did not learn" from moving on to the next grade - but also symbolic, because it is used as a means of condemning or approving students' behavior. Evidence of this role are phrases that are constantly repeated during the meetings: "what message will we be sending her?", "what kind of message are we getting through to them?"

Thus, students are prevented from moving on to the next grade so that they can learn the curriculum, but also the behavior and values considered correct according to the school's morality.

It is evident that the notion of meritocracy has specific characteristics in this school. The ideas of merit and justice are not defined only by cognitive value, but also - and perhaps, mainly - by moral values.

As a consequence, different conceptions of justice appear as the criteria used by each teacher as he or she follows his or her representations of what is adequate behavior for each student - and, in some cases, for their families. 
Therefore, the idea of justice is linked to the idea of merit, which in turn, is determined by moral values. But what determines which moral values make failing a student fair or unfair? Why do some students deserve to be approved and others not?

To answer these questions, it is necessary to understand the principles that organize the school's classification system: these moral conceptions are not produced in a vacuum. On the contrary, they are built on dynamics of interaction, in a process in which both students and teachers participate. In this way, it is necessary to look at what happens inside the classroom, as this is the most significant space for the interactions among these elements, and where the categories and representations are built.

The observations in classrooms made me perceive that students who were more frequently cited at the student evaluation board meetings were also those with whom the teacher interacted more in classrooms. This relation is not connected to the quality of the classifications or interactions, but to their volume. In the same way, students who were "invisible" at the meetings, those who were never mentioned by the teachers, underwent a similar process in classrooms: they were often ignored by teachers, who seldom spoke to them (Mascarenhas 2013).

Apart from the classroom, another way that could help us understand how the school's classificatory system is constructed would be to analyze the relation between moral values and the teachers' representations of their own social roles and those of their students.

I believe that the teachers' expectations regarding these roles occupy a central place in this system. In the scale of morality, the categories that have the lowest moral value in the student evaluation board meeting ${ }^{23}$ were those associated with behaviors that challenged the demands and rules of the school. When I asked teachers to tell me about disagreeable situations in the school, they said that this type of student behavior caused feelings of "anger" and of being "disrespected." They felt that their authority and teaching skills—-their very identity in effect—were under threat.

In contrast, positive evaluations reinforced the teacher's role and identity. The reports of situations that involved "dedicated," "interested" students, as

23 Aside from the student evaluation board meetings, these categories appeared in the interviews with the teachers. In them, I asked the teachers to point out students and situations they considered "positive" or "negative." The elements they mentioned corresponded to the categories used at the board meetings. 
well as those who "respected" the teacher, were associated with positive emotions such as "pride," "satisfaction" and "recognition."

In this regard, we can say that the indicator of the scale of morality is precisely how much a behavior or a characteristic threatens the teacher's social role and identity. The students' range of action and his/her arbitrariness in the face of his/her academic situation and behavior are also an important factor in the hierarchy of moral judgment.

To defend their position when confronted with the academic fate of a student, teachers used discursive strategies to attribute a wider or narrower range of action to students. It is in this sense that family dramas, problems of health, specific personality traits and morality become more important, as they are manipulated by teachers as they argue in defense of what they assume to be the best interests of their students. ${ }^{24}$.

Moral evaluations are of course not confined to the school I studied, They pervade and indeed constitute all social life. I hope, therefore, that my analysis of a Brazilian school may also contribute to wider understandings of Brazilian society as a whole.

Received November 1, 2014, Approved June 17, 2015

Translated by Thomas Muello

Revised by Peter Fry

\section{References}

ABREU, Alzira. 1992. Intelectuais e guerreiros. Rio de Janeiro: UFRJ. BARBOSA, Maria Lígia; RANDALL, Laura. 2004. "Desigualdades sociais e formação de expectativas familiares e de professores". Cadernos do CRH, 17(14): 299-308.

BOURDIEU, Pierre. 1999. "As categorias do juízo professoral”. In: Maria Alice Nogueira \& A. Catani (orgs.), Escritos de educação. Petrópolis: Editora Vozes. pp. 185-216.

CARVALHO, Marilia Pinto de. 2001. "Mau aluno, boa aluna? Como as professoras avaliam meninos e meninas”. Estudos Feministas, 9(2): 554-574.

24 This manipulation involves a process to raise compassion by victimizing the student. When compassion does come into play, other feelings are triggered, such as a need for vengeance or punishment. 
DURKEIM, Émile. 200o. As formas elementares da vida religiosa. São Paulo: Martins Fontes.

GALVÃO, Maria Cristina da Silva. 2007. "Quem são os alunos que vencem o percurso escolar numa escola pública de prestígio? O caso do Colégio Pedro II". 30 $0^{a}$ Reunião Anual da Associação Nacional de Pós-Graduação e Pesquisa em Educação (ANPED), Caxambu. Mimeo.

GOMES, Raquel Ferreira Rangel. 2012. Ainda somos os mesmos: classificação, organização e ethos escolar. Dissertação de Mestrado em Sociologia, PPGSA, UFRJ, Rio de Janeiro.

KAIUCA, Míriam Abduche. 2004. "Com um lápis e um papel ... cria-se um novo texto: as representações de práticas democráticas nos colégios de aplicação". Ensaio: Avaliação e Políticas Públicas em Educação, 12(45): 10131044.

LAGE, Giselle Carino. 2010. Uma luz no fim do túnel: um estudo de caso em uma escola diferente. Dissertação de Mestrado, PPGSA, UFRJ, Rio de Janeiro.

MASCARENHAS, Maíra. 2013. Quem é ele, onde ele senta? Um estudo sobre classificação e moral em uma escola pública do Rio de Janeiro. Dissertação de Mestrado, PPGSA, UFRJ, Rio de Janeiro.

PRADO, Ana Pires; SÁ EARP, Maria de Lurdes. 2011. "Os conselhos de classe: mecanismos de produção das desigualdades na escola?" 34르 Reunião Anual da Associação Nacional de Pós-Graduação e Pesquisa em Educação (ANPED), Natal. Mimeo.

RIBEIRO, Sérgio Costa. 1991. "A pedagogia da repetência”. Estudos Avançados, 5(12): 7-18.

SÁ EARP, Maria de Lurdes. 2006. A cultura da repetência em escolas cariocas. Tese de Doutorado, PPGSA, UFRJ, Rio de Janeiro.

SCHNEIDER, Dorothy. 1981. “Alunos excepcionais': um estudo de caso de desvio". In: Gilberto Velho (org.), Desvio e divergência. Rio de Janeiro: Zahar. pp. 52-82.

VELHO, Gilberto. 1978. “Observando o familiar”. In: Edison de O. Nunes (org.), A aventura sociológica. Rio de Janeiro: Zahar. pp. 36-46.

\section{Maíra Mascarenhas}

Fundação Roberto Marinho

mmascarenhasp@gmail.com 